\title{
Internet of Things on Electrical Energy Monitoring Using Multi-Electrical Parameter Sensors
}

\section{Internet of Things pada Monitoring Energi Listrik Menggunakan Sensor Multi-Parameter Listrik}

\author{
Risfendra ${ }^{*}$, Gheri Febri Ananda ${ }^{1}$, Alphin Stephanus ${ }^{2}$
}

\begin{abstract}
This study aims to apply the Internet of Things to monitoring electricity energy consumption. The system is designed to replace the manual and conventional measurement of electrical energy. Uncontrolled use of electricity is one of the causes of high levels of electrical energy consumption. Therefore, consumers need to know the amount of electrical energy consumption in real-time. The device is designed using the PZEM$004 T$ which is used as a sensor to read electrical multi-parameter, Arduino as the main control, and ESP8266 as a data sender on the Cloud system. The test results showed that the device has been able to read and display electricity quantity data in the form of voltage, current, power, and electricity tariff accumulation in real-time displayed on the ThingSpeak platform. The test on the PZEM-004T sensor has an accuracy rate of $94.96 \%$ for reading current values and $99.42 \%$ for reading voltage values.
\end{abstract}

\section{Keywords}

Electrical energy, Parameter, real-time

\begin{abstract}
Abstrak
Penelitian ini bertujuan untuk menerapkan teknologi Internet of Things pada monitoring konsumsi energi listrik. Sistem dirancang untuk menggantikan pengukuran energi listrik yang masih manual dan konvensional. Penggunaan listrik yang tidak terkontrol merupakan salah satu penyebab tingginya tingkat pemakaian energi listrik. Oleh karena itu, konsumen perlu mengetahui jumlah pemakaian energi listrik secara realtime. Alat dirancang menggunakan PZEM-004T yang digunakan sebagai sensor untuk membaca multi-parameter listrik, Arduino sebagai kendali utama, dan ESP8266 sebagai pengirim data pada sistem Cloud. Hasil pengujian menunjukan bahwa alat telah mampu membaca dan menampilkan data besaran listrik berupa tegangan, arus, daya, dan akumulasi tarif listrik secara realtime yang ditampilkan pada platform ThingSpeak. Pengujian pada sensor PZEM-004T memiliki tingkat akurasi 94.96\% untuk pembacaan nilai arus dan 99. $42 \%$ untuk pembacaan nilai tegangan.
\end{abstract}

\section{Kata Kunci}

Energi listrik, Parameter, realtime

${ }^{1}$ Jurusan Teknik Elektro, Universitas Negeri Padang

Fakultas Teknik, Kampus UNP Air Tawar Barat, Jl.Prof.Dr. Hamka, Padang.

${ }^{2}$ Jurusan Teknik Elektro, Politeknik Negeri Ambon

Jl. Ir. M. Putuhena, Rumah Tiga, Tlk. Ambon, Kota Ambon, Maluku, Indonesia.

*gherifebriananda@gmail.com

Submitted : October 02, 2020. Accepted : October 12, 2020. Published : January 15, 2021. 


\section{PENDAHULUAN}

Pada saat ini, semakin banyak kebutuhan dan tuntutan yang sering muncul dalam keseharian manusia. Salah satunya dalam bidang kelistrikan. Listrik merupakan kebutuhan utama bagi setiap aspek kehidupan masyarakat, baik itu dalam bidang industri, bisnis, ataupun rumah tangga. Pemakaian listrik yang semakin lama semakin meningkat menyebabkan kelangkaan energi listrik [1].

Berdasarkan data statistik PLN tahun 2018, penggunaan listrik pada tahun 2018 sebesar 234.617,88 GWh meningkat sebesar 5,15\% dari tahun sebelumnya. Sedangkan jumlah pelanggan pada akhir tahun 2018 sebesar 71.917 .397 pelanggan meningkat 5,65\% dari akhir tahun 2017. Kelompok rumah tangga berada pada tingkat pertama pemakaian listrik yaitu sebesar 97.832,28 GWh (41,70\%), selanjutnya kelompok industri sebesar 76.946,50 GWh $(32,80 \%)$, bisnis $44.027,40 \mathrm{GWh}(18,77 \%)$, dan lainnya (sosial, gedung pemerintah dan penerangan jalan umum) $15.811,70 \mathrm{GWh}(6,74 \%)$ [2].

Penggunaan listrik yang tidak terkontrol, terutama pada rumah tangga dapat menyebabkan tingginya konsumsi dalam pemakaian energi listrik. Untuk melakukan manajemen konsumsi energi listrik di rumah, tidak cukup hanya dengan menggunakan kWh meter saja karena alat tersebut hanya untuk mengukur pemakaian listrik secara keseluruhan. Agar pengguna dapat memantau penggunaan energi listrik secara realtime, maka diterapkan monitoring konsumsi energi listrik berbasis Internet of Things. Internet of Things merupakan suatu konsep yang bertujuan untuk memperluas manfaat dari konektivitas internet yang tersambung secara terus menerus, seperti kemampuan dalam mengirim dan menerima data informasi dan komunikasi. Pada dasarnya, Internet of Things mengacu pada kemampuan objek atau benda-benda yang terkoneksi dengan jaringan internet [3]. Teknologi IoT ini sudah banyak diterapkan dalam beberapa penelitian sebelumnya seperti pada Pemanfaatan IoT cloud untuk sistem pendeteksi dini bencana banjir [4], Sistem monitoring Arus, Tegangan dan Intensitas Cahaya pada Panel Surya [5] dan pada penelitian lainnya..

Pada penelitian sebelumnya yang berjudul "Rancang Bangun Monitoring Energi Listrik Menggunakan SMS Berbasis Mikrokontroler Atmega328" melakukan monitoring energi listrik hanya melalui SMS [6]. Sehingga pada penelitian ini dikembangkan suatu sistem monitoring menggunakan teknologi Internet of Things dengan ESP8266 untuk menghubungkan sistem pada Cloud, mikrokontroler Arduino sebagai kendali utama, dan modul PZEM-004T sebagai sensor untuk mengukur besaran listrik berupa tegangan, arus, dan daya listrik. Dengan menerapkan sistem Internet of Things ini, pengguna dapat memonitoring penggunaan energi listrik secara realtime dan device monitor yang digunakan dapat berupa PC maupun smartphone.

\section{Modul PZEM-004T}

PZEM-004T merupakan sebuah modul sensor/ hardware yang berfungsi untuk mengukur parameter tegangan, arus, daya aktif, dan konsumsi daya (Wh) yang terdapat pada aliran listrik. Pengkabelan dari modul ini memiliki 2 bagian, yaitu pengkabelan terminal masukan tegangan dan arus, serta pengkabelan komunikasi serial. Modul ini sudah dilengkapi sensor tegangan dan sensor arus (CT) yang sudah terintegrasi. Dalam penggunaannya, alat ini khusus untuk penggunaan dalam ruangan (indoor) dan sensor ini dapat mengukur arus listrik dengan maksimal 100 A.[7]. 


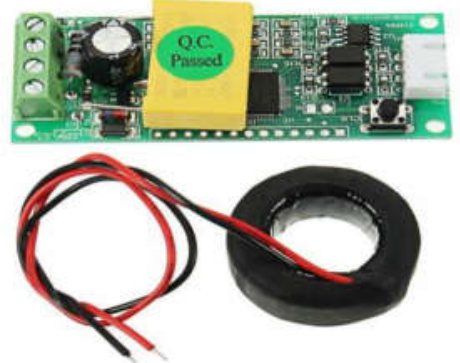

(a)

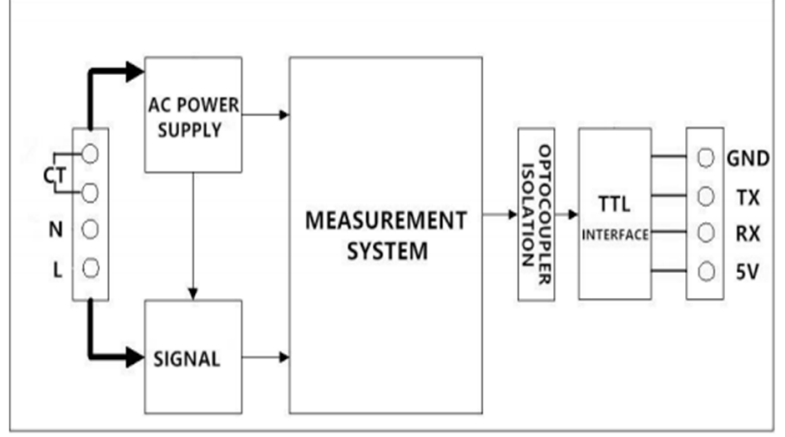

(b)

Gambar 1. Modul PZEM-004T (a) Bentuk fisik (b) Konfigurasi Port [7]

\section{Internet of Things}

Teknologi Internet of Things merupakan suatu infrastruktur global yang digunakan masyarakat dalam hal informasi yang memungkinkan layanan dengan menghubungkan objekobjek (Things) baik fisik maupun virtual. Teknologi IoT berkembang pesat dengan cepat, baik dalam bidang industri, sistem keamanan, pendidikan, maupun transportasi yang sudah diterapkan dalam menjalankan aktifitasnya. Dengan demikian, IoT sudah menjadi bagian dari kehidupan manusia. Gambar 2 menjelaskan beberapa penerapan IoT dalam kehidupan serta fungsinya masing-masing.

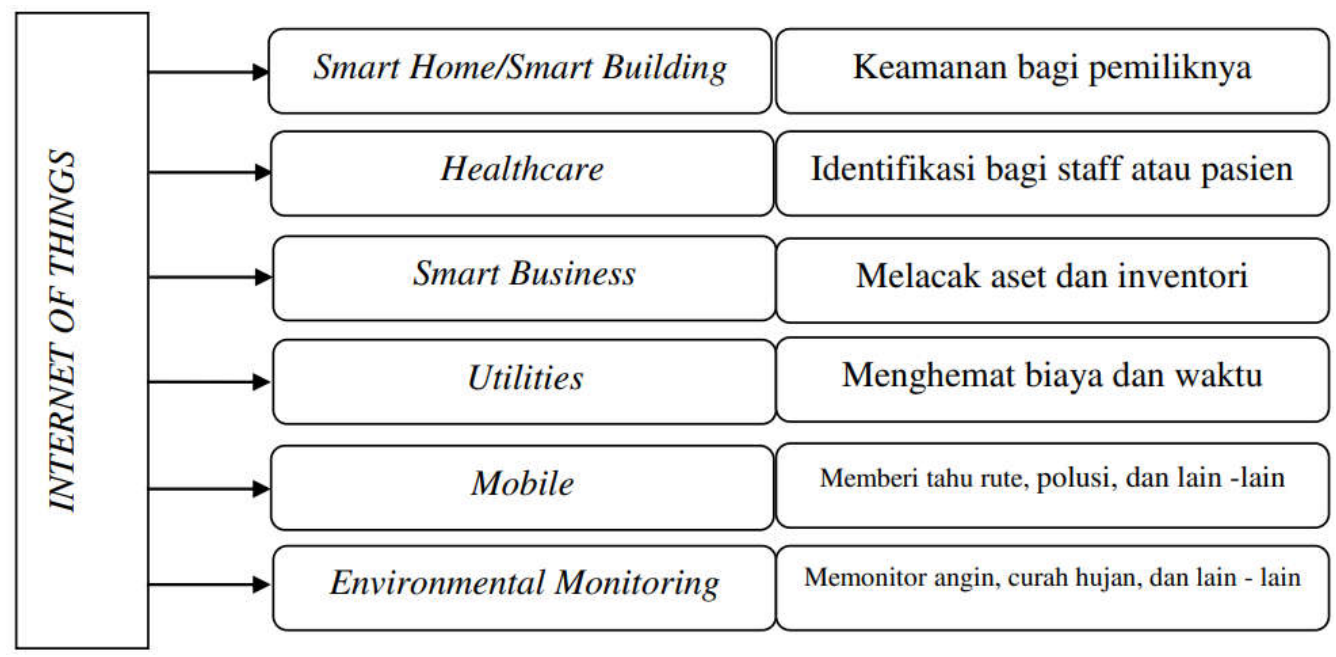

Gambar 2. Contoh Pengaplikasian IoT [8]

\section{METODE PENELITIAN}

Metode penelitian yang digunakan yaitu kuantitatif, dimana akan diperoleh data berupa nilai akurasi sensor dan keberhasilan pengiriman data energi listrik pada Cloud. Penelitian dimulai dari perancangan alat yang secara ringkas digambarkan pada blok diagram pada Gambar 3 berikut. 


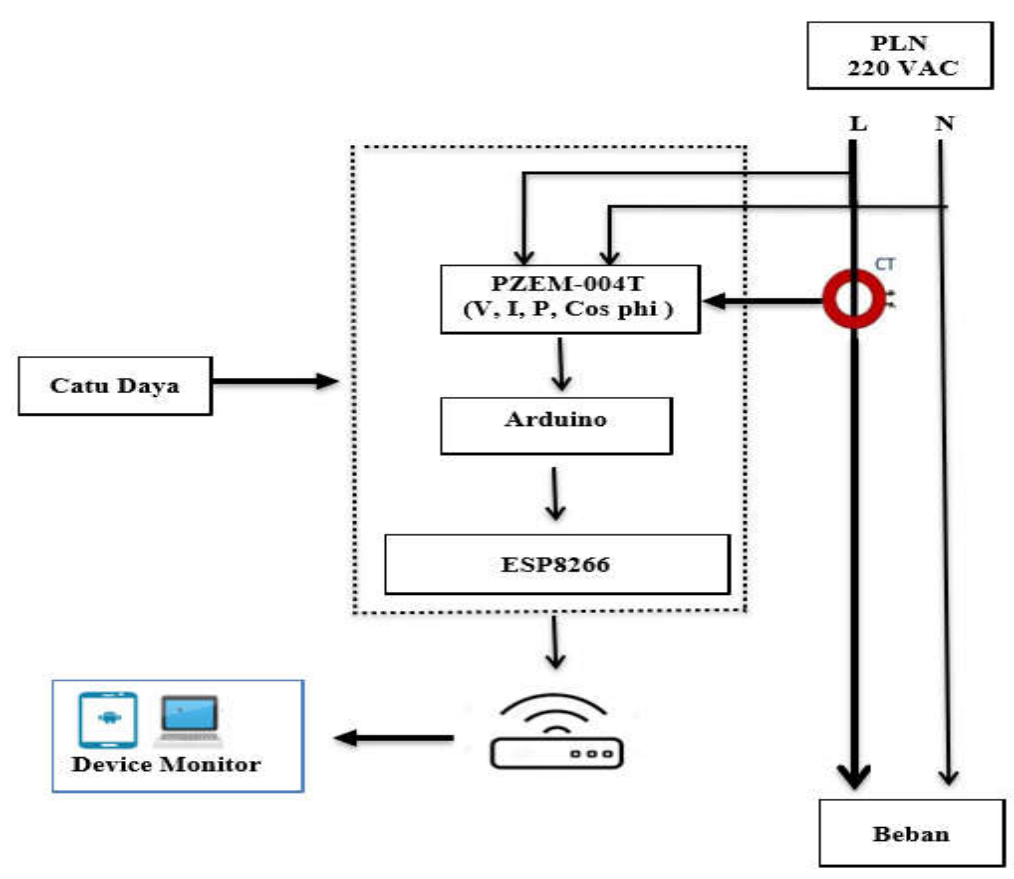

Gambar 3. Blok Diagram Sistem

Sistem kerja alat dimulai dari sensor PZEM-004T untuk membaca data tegangan, arus, daya, dan cos phi. Data tersebut diteruskan ke mikrokontroller Arduino untuk diproses melalui komunikasi serial $(\mathrm{Rx}, \mathrm{Tx})$. Terminal input sensor langsung terhubung dengan jaringan listrik $220 \mathrm{~V}$ dan terminal komunikasi sensor terhubung dengan pin $\mathrm{Rx}, \mathrm{Tx}$ Arduino. Untuk konfigurasi dari sensor PZEM-004T seperti terlihat pada Gambar 4 berikut .

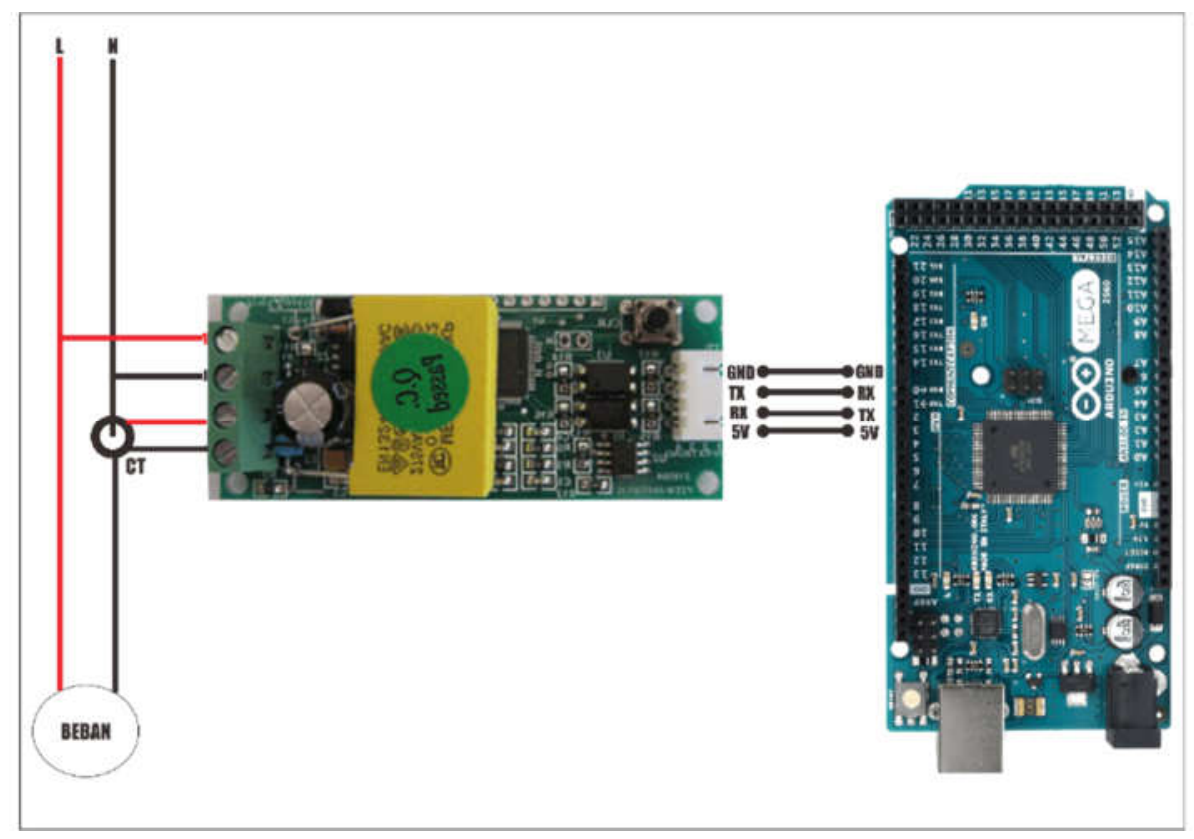

Gambar 4. Konfigurasi Sensor dengan beban dan Arduino

Data yang telah diproses pada mikrokontroller lalu dikirimkan ke sistem Cloud melalui ESP8266 untuk ditampilkan pada device monitor menggunakan platform ThingSpeak. Untuk Konsumsi energi listrik alat ini sendiri setelah dilakukan pengukuran yaitu sebesar 3.3 Watt. Gambar 5 menunjukkan bentuk fisik dari sistem secara keseluruhan. 


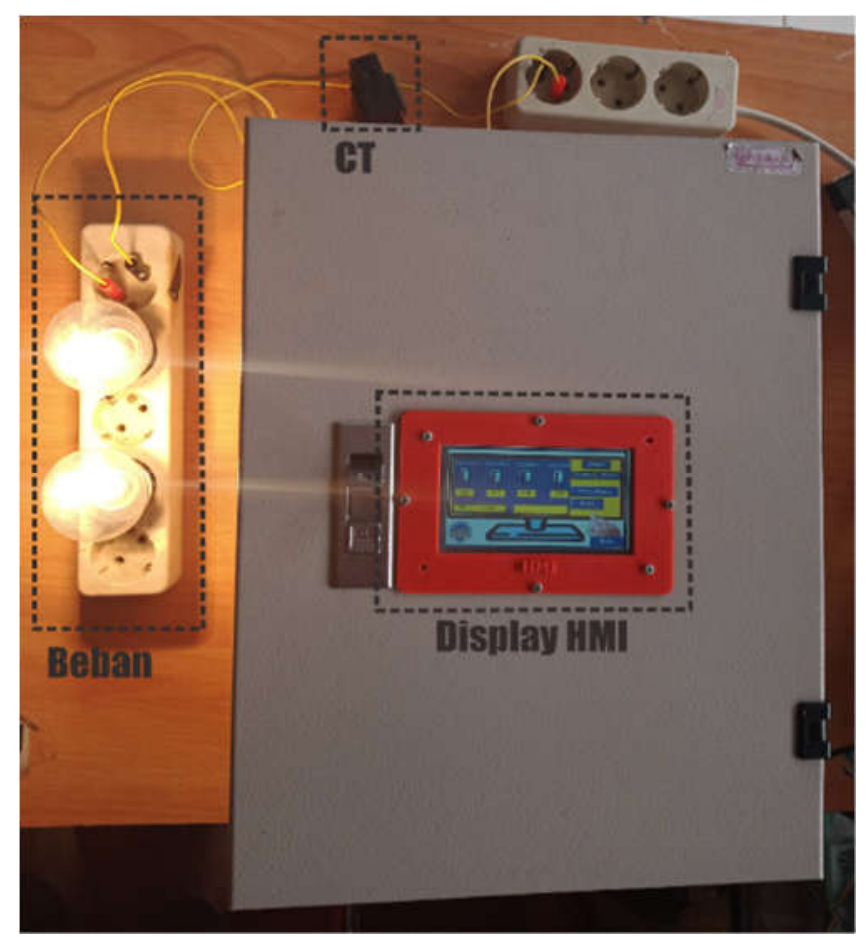

Gambar 5. Bentuk Fisik Sistem Monitoring Energi Listrik

\section{Cara Pengambilan Data}

Untuk mengetahui error hasil pengujian, dilakukan dengan cara membandingkan hasil pembacaan sensor dengan pembacaan alat ukur standar. Untuk menghitung tarif energi listrik dapat dihitung degan rumus:

$$
\begin{array}{ll}
\mathrm{P} & =\mathrm{V} \times \mathrm{I} \times \text { Cos phi } \\
\mathrm{W} & =\mathrm{P} \times \mathrm{t} \\
\text { Tarif listrik } & =\mathrm{W} \times \text { tarif PLN (per Kwh) } / 1000
\end{array}
$$
Keterangan:

$$
\begin{array}{ll}
\mathrm{P} & =\text { Daya aktif }(\mathrm{W}) \\
\mathrm{V} & =\text { Tegangan }(\mathrm{V}) \\
\mathrm{I} & =\text { Arus } \quad(\mathrm{A}) \\
\mathrm{W} & =\text { Energi Listrik (Joule) } \\
\mathrm{KWh} & =\text { Energi listrik dalam satu jam }
\end{array}
$$

Sedangkan untuk pengujian data Cloud, sistem disetting untuk mengirim data setiap lima menit dalam jangka waktu selama satu jam untuk melihat kinerja pengiriman data dari sistem.

\section{HASIL DAN PEMBAHASAN}

Pengujian yang dilakukan meliputi uji kinerja sensor dan keberhasilan dalam pengiriman data pada Cloud secara realtime. Pengujian sensor dilakukan dengan cara membandingkan hasil pembacaan dari sensor dengan alat ukur standar yang umum digunakan. Jika hasil pembacaan sensor baik, maka alat juga akan bekerja dengan baik. Alat ukur pembanding yang digunakan adalah tang ampere dengan merk Sanwa. Hasil pengukuran terlihat pada Tabel 1 dan Tabel 2 berikut. 
Tabel 1. Hasil data pengujian sensor untuk pembacaan arus listrik (A)

\begin{tabular}{|c|l|l|l|l|}
\hline No & \multicolumn{1}{|c|}{ Jenis Beban } & $\begin{array}{c}\text { Hasil Pengukuran } \\
\text { Alat Ukur }\end{array}$ & \multicolumn{1}{|c|}{$\begin{array}{c}\text { Hasil Pembacaan } \\
\text { Sensor }\end{array}$} & \multicolumn{1}{|c|}{ Keterangan } \\
\hline 1 & Tanpa Beban & 0 & 0 & $100 \%$ \\
\hline 2 & 1 x TL 36 Watt & 0.48 & 0.51 & $93.75 \%$ \\
\hline 3 & 2x TL 36 Watt & 0.98 & 1.03 & $94.90 \%$ \\
\hline 4 & 1 x Motor Induksi $1 / 4$ HP & 1.87 & 1.94 & $96.25 \%$ \\
\hline
\end{tabular}

Tabel 2. Hasil data pengujian sensor untuk pembacaan tegangan listrik (V)

\begin{tabular}{|l|l|l|l|}
\hline Pengujian ke- & Hasil Pengukuran Alat Ukur & Hasil Pembacaan Sensor & \multicolumn{1}{|c|}{ Keterangan } \\
\hline 1 & 234 & 234 & $100 \%$ \\
\hline 2 & 230 & 233 & $98.7 \%$ \\
\hline 3 & 231 & 232 & $99.57 \%$ \\
\hline 4 & 228 & 230 & $99.13 \%$ \\
\hline 5 & 230 & 231 & $99.57 \%$ \\
\hline 6 & 232 & 233 & $99.57 \%$ \\
\hline 7 & 235 & 235 & $100 \%$ \\
\hline 8 & 229 & 230 & $99.57 \%$ \\
\hline
\end{tabular}

Berdasarkan Tabel 1 dan Tabel 2 menunjukan bahwa sensor PZEM004T memiliki nilai akurasi pengukuran arus saat berbeban dengan rata-rata $94.96 \%$ dan $100 \%$ saat pengukuran tidak berbeban. Sedangkan untuk pembacaan tegangan memiliki akurasi rata-rata 99.51\%. Grafik hasil pembacaan sensor dan alat ukur terlihat pada Gambar 6 berikut.

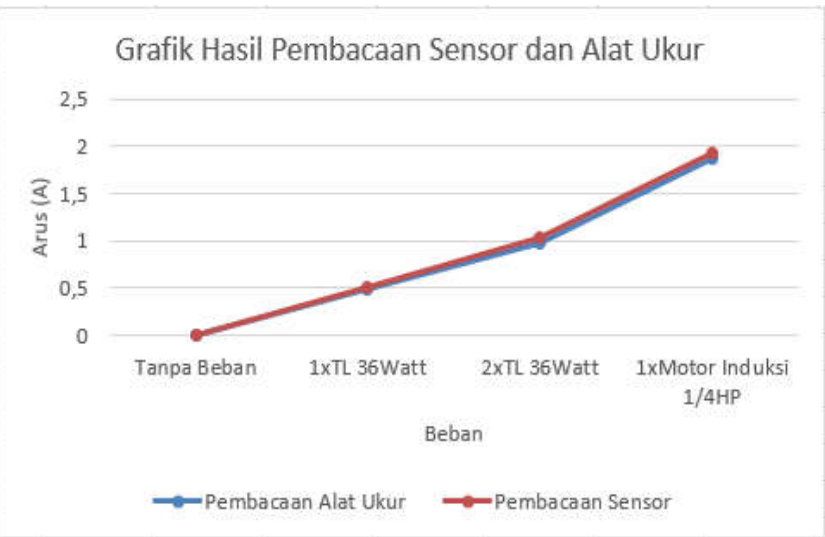

(a)

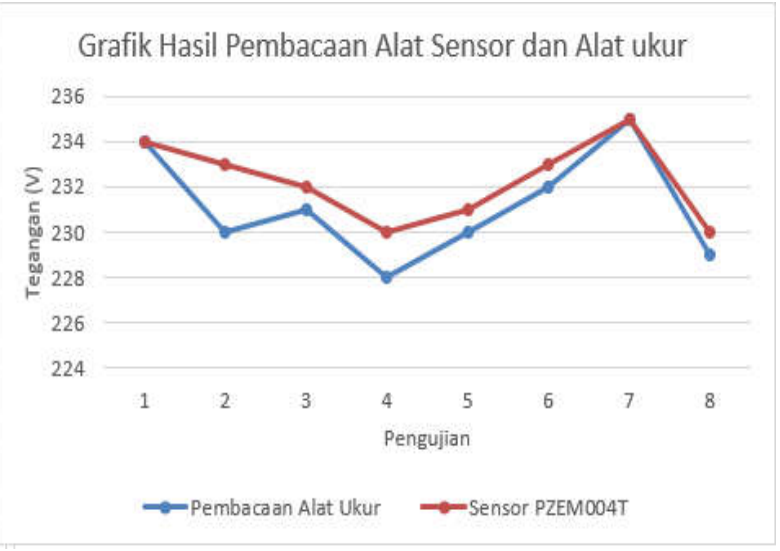

(b)

Gambar 6. (a) Grafik hasil pembacaan arus (b) Grafik hasil pembacaan tegangan

Selanjutnya Tabel 3 menunjukkan hasil pengujian pengiriman data pada Cloud setiap lima menit dalam jangka waktu satu jam. Pengujian dilakukan menggunakan beban dua buah lampu pijar dengan daya 75 watt.

Berdasarkan Tabel 3 terlihat dari pukul 16.49 sampai dengan 17.49 semua data sensor sukses dikirim ke cloud dengan ini membuktikan komunikasi serial antara ESP8266 dan Arduino sudah berjalan dengan baik. Tampilan pada device monitor seperti yang terlihat pada Gambar 7 dan 8. 
Tabel 3. Hasil Pengiriman Data pada Cloud selama Satu Jam

\begin{tabular}{|l|l|l|l|l|}
\hline \multicolumn{1}{|c|}{ Waktu } & \multicolumn{1}{|c|}{ Tegangan (V) } & \multicolumn{1}{|c|}{ Arus (A) } & \multicolumn{1}{|c|}{$\begin{array}{c}\text { Darif Listrik } \\
(\mathrm{Rp})\end{array}$} \\
\hline $16: 54$ & 233 & 0.65 & 152 & 13.95 \\
\hline $16: 59$ & 233 & 0.65 & 152 & 28.81 \\
\hline $17: 04$ & 234 & 0.65 & 153 & 43.68 \\
\hline $17: 09$ & 234 & 0.65 & 154 & 58.67 \\
\hline $17: 14$ & 235 & 0.65 & 154 & 73.70 \\
\hline $17: 19$ & 236 & 0.66 & 156 & 88.80 \\
\hline $17: 24$ & 236 & 0.66 & 155 & 103.88 \\
\hline $17: 29$ & 235 & 0.65 & 155 & 118.95 \\
\hline $17: 34$ & 235 & 0.65 & 154 & 133.98 \\
\hline $17: 39$ & 233 & 0.65 & 152 & 148.87 \\
\hline $17: 44$ & 232 & 0.65 & 152 & 163.72 \\
\hline $17: 49$ & 234 & 0.65 & 153 & 178.51 \\
\hline Keterangan & Sukses & Sukses & Sukses & Sukses \\
\hline
\end{tabular}

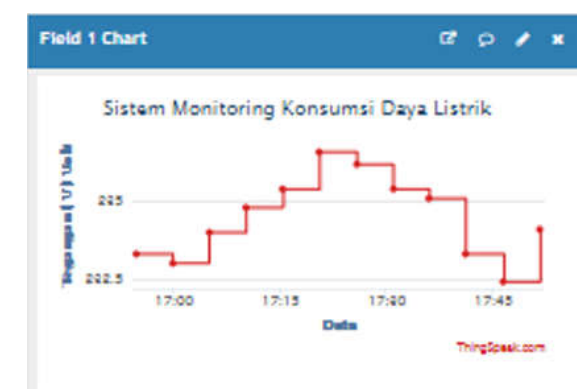

(a)

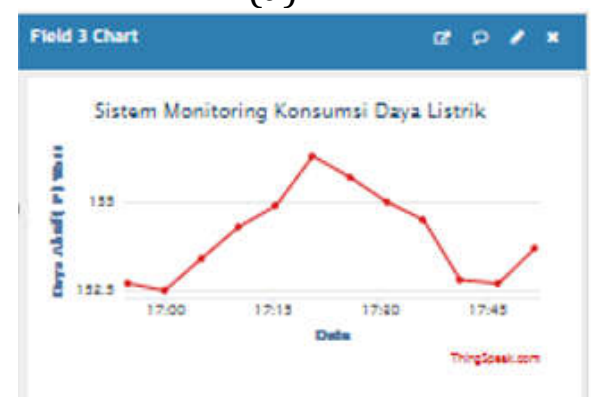

(c)

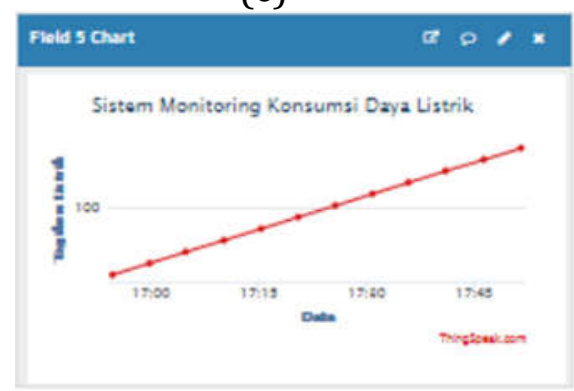

(e)

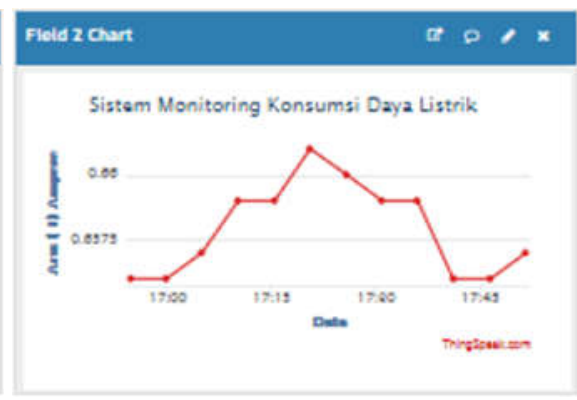

(b)

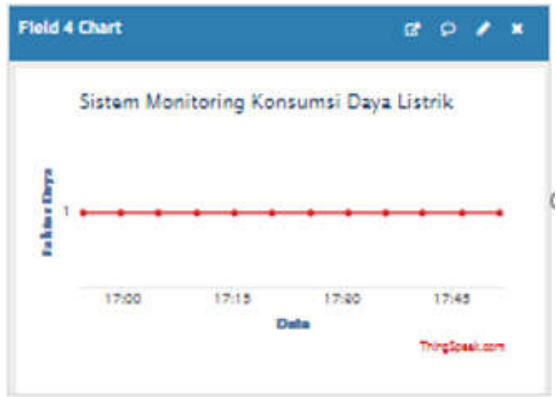

(d)

Gambar 7. Tampilan Data pada PC (a) V (b) I (c) P (d) cos phi (e) Tarif listrik 


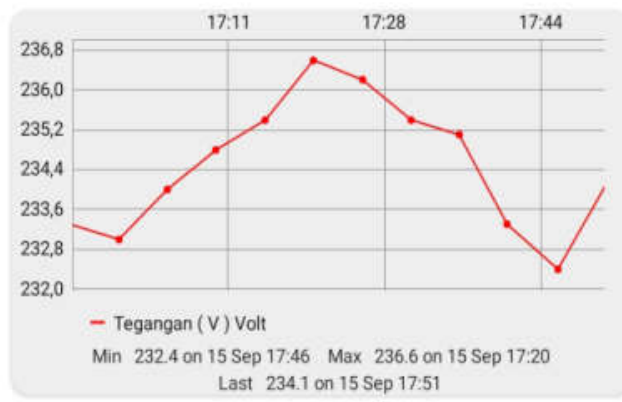

(a)

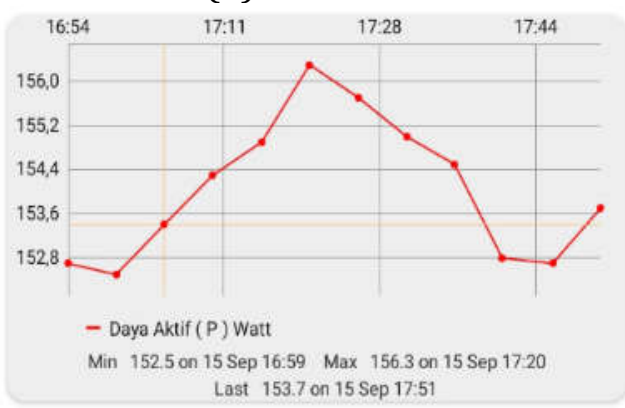

(c)

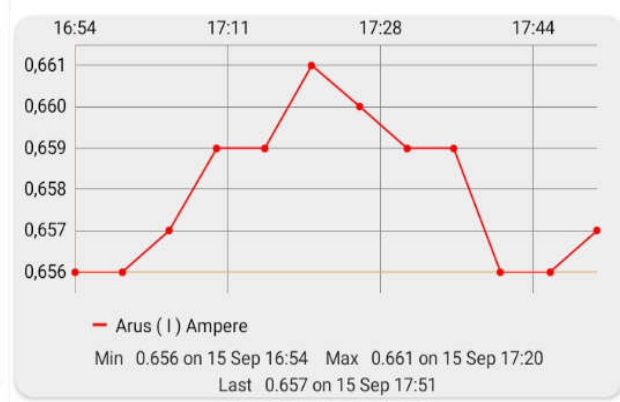

(b)

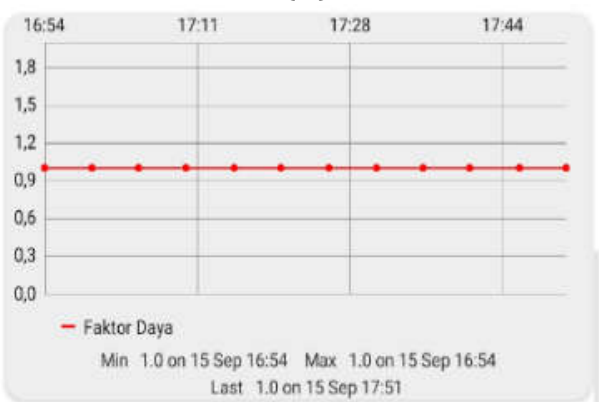

(d)

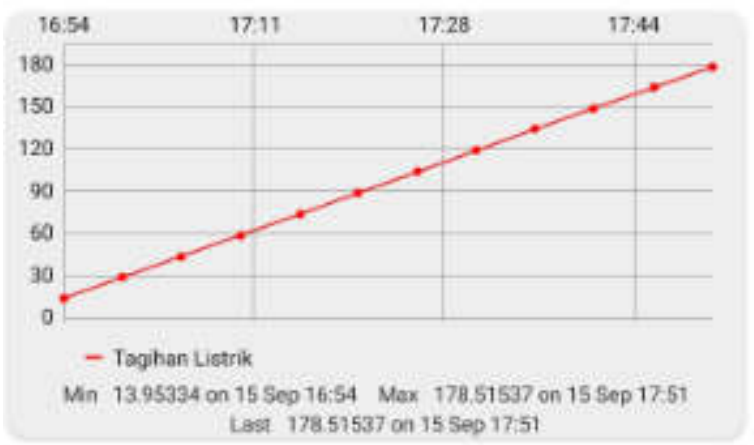

(e)

Gambar 8. Tampilan Data pada Smartphone (a) V (b) I (c) P (d) cos phi (e) Tarif listrik

\section{SIMPULAN DAN SARAN}

\section{Simpulan}

Dari penelitian yang dilakukan dapat disimpulkan bahwa penerapan Internet of Things pada monitoring energi listrik menggunakan modul PZEM-004T berjalan sesuai dengan yang dirancang. Sistem sudah mampu untuk mengirimkan data pada Cloud secara realtime dan sudah dapat dimonitoring melalui device monitor berupa PC maupun smartphone. Sedangkan untuk kinerja sensor modul PZEM-004T memiliki nilai akurasi pengukuran arus saat berbeban dengan rata-rata $94.96 \%$ dan $100 \%$ saat pengukuran tidak berbeban. Sedangkan untuk pembacaan tegangan memiliki akurasi rata-rata $99.51 \%$.

\section{Saran}

Pada penelitian kedepannya, sistem ini dapat dikembangkan pada monitoring energi listrik pada jaringan tiga fasa karena untuk sensor PZEM-004T itu sendiri mampu untuk mengukur arus hingga $100 \mathrm{~A}$. Dan untuk penerapan Internet of Things dapat dikembangkan untuk implementasi pada penerapan lainnya yang memerlukan pemantauan secara berkelanjutan. 


\section{DAFTAR RUJUKAN}

[1] Masykur, Fauzan, and Fiqiana Prasetiyowati, "Aplikasi Rumah Pintar (Smart Home) Pengendali Peralatan Elektronik Rumah Tangga Berbasis Web," Jurnal Teknologi Informasi dan Ilmu Komputer, vol. 3, no. 1, pp. 51-58, 2016.

[2] Sekretariat Perusahaan PT PLN (Persero), Statistik PLN 2018, Jakarta:PT PLN, 2018.

[3] Meutia and Ernita Dewi, "Dampak Sosial Internet of Things," Seminar Nasional dan Expo Teknik Elektro, pp. 102-106, 2017.

[4] Hadi, Mokh Sholihul. "IoT Cloud Data Logger Untuk SIstem Pendeteksi Dini Bencana Banjir Pada Pemukiman Penduduk Terintegrasi Media Sosial," Jurnal Edukasi Elektro, vol. 1, no. 2, 2017.

[5] Aritonang, Cahaya Lidya, and Yosi Riduas Hais. "Sistem Monitoring Tegangan, Arus, dan Intensitas Cahaya pada Panel Surya dengan Thingspeak." Jurnal Engineering, vol. 2, no. 1, pp. 11-24, 2020

[6] Ramadhianti, Raden Ajeng Gusti, C. G. I. Partha, and I. G. A. P. R. Agung, "Rancang Bangun Monitoring Energi Listrik Menggunakan SMS Berbasis Mikrokontroler Atmega328,” EJournal SPEKTRUM, vol. 5, no. 1, pp. 130-138, 2018.

[7] Makhabbah, Haqqu, and Achmad Imam Agung, "Rancang Bangun Sistem Monitoring Konsumsi Daya Listrik Dan Pemutus Daya Otomatis Berbasis Internet," ." JURNAL TEKNIK ELEKTRO, vol. 9, no. 1, 2020.

[8] Asghar, Mohsen Hallaj, Atul Negi, and Nasibeh Mohammadzadeh, "Principle application and vision in Internet of Things (IoT)," International Conference on Computing, Communication \& Automation. IEEE, pp. 427-431, 2015. 
Halaman ini sengaja dikosongkan 